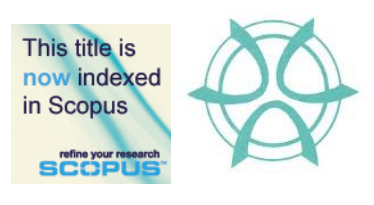

PLANNING MALAYSIA:

Journal of the Malaysian Institute of Planners

VOLUME 16 ISSUE 1 (2018), Page 294 - 302

\title{
SYMBOLISM IN TRADITIONAL MALAY BOAT CRAFTING IN THE EAST COAST
}

\author{
Mohd Rohaizat Abdul Wahab ${ }^{1}$, Zuliskandar Ramli ${ }^{2}$, Nurul Norain \\ Akhemal Ismail ${ }^{3}$, Nuratikah Abu Bakar ${ }^{4}$, \& Wan Nor Shamimi Wan \\ Azhar $^{5}$ \\ ${ }^{1}$ Institute for Mathematical Research \\ UNIVERSITI PUTRA MALAYSIA \\ ${ }^{2,3,4,5}$ Institute of The Malay World and Civilization \\ UNIVERSITI KEBANGSAAN MALAYSIA
}

\begin{abstract}
The culture in the East Coast are rich in visual arts and performing arts inherited over time immemorial. The art is also found to have similarities in three different states, despite their geographical gap. The similarities are shared in dialects, languages, presentations, builds, and past legacy artefacts. The Malay craftsmanship is also dominated by the Malay community in the East Coast and it is also produced in the form of art and fashion. Artefacts such as boats, houses, and furniture are still visible until now and they have high artistic value. This research is aimed at displaying symbols produced by the Malay community on the craft of the boat. This art can be seen in the carvings and paintings produced on traditional Malay boats in the East Coast. This art does not only serve as an ornament and for its aesthetics, but also has its own symbolism. The decorative art produced shows that the three main aspects necessary in Malay art are function, aesthetics, and ethics. The belief in the existence of supernatural powers - which preserve and safeguard their safety at sea and their ability to get income from marine products - underpins the craft of this decoration art.
\end{abstract}

Keywords: symbolism, environment, boat, crafting 
PLANNING MALAYSIA

Journal of the Malaysia Institute of Planners (2018)

\section{INTRODUCTION}

Water transport is one of the most important features in Malay-Polynesian culture. The Malay community's knowledge in sailing and activities related to the ocean has long been dominated by the Malay community. According to Nik Hassan Shuhaimi (2002), since the Neolithic period (especially in the late Neolithic) people in the East Coast have learned to build boats and are skilled in using them. In the Malay culture in the East Coast, boats are used in daily activities; hence, their communities have produced various types of boats that can be customized to their function and usability. For example, a small line boat is used in river and coastal areas, the payang boat used by deep-sea fishermen, and the jokong boat is used to transport heavy goods. The various production of these types of boats is also owed to the easy access to tropical timber resources and their geographical location, which is in the East Coast and is close to the South China Sea. The ocean has also provided a great source of livelihood to the fishermen community in the East Coast. The rapid and lucrative income has attracted the attention of many East Coast residents to get involved in fishing.

Arts and craft in the Malay culture in the East Coast are well-known and unique. This art can be seen in the construction of Malay houses, ironwork, brass, songket weaving, batik making, boat crafting, and many other arts produced by communities in the East Coast. In the production of boats in the East Coast, the decoration aspect is strongly emphasized by the fishermen. The boats produced by the Malay community are decorated with attractive engravings and paintings. Among the ornaments embodied in the boat are carvings and paintings on linggi, bangau (stork), okok, caping, sangga tengah, sangga kemudi, cagak, and koyang. However, most of the traditional Malay boats are in danger of extinction due to the presence of the modern boat, which is easier to maintain rather than wooden boats. According to Sheppard (1963), since 1945, fishermen in the East Coast have preferred to use engine in place of sail, which also resulted in a major change to the traditional Malay boat decoration.

\section{PROBLEM STATEMENT}

The use of traditional Malay boats among the fishermen in the East Coast is increasingly diminished due to the pressure of modernization, the difficulty in obtaining timber resources, and higher boat maintenance costs compared to that of glass fibre boats. This situation has resulted in a lack of traditional boat booking requests and loss of income among traditional boat entrepreneurs. Nowadays, it is difficult to see traditional Malay boats still in use by fishermen, except for several places in the states of Kelantan and Terengganu. Nik Hassan Shuhaimi (2010) suggests that there should be an in-depth study of the traditional Malay boats to ensure the preservation of the richness of the Malay maritime tradition of Malay culture and the knowledge of the Malay sailing boats, as well as to educate the current generation of its importance. This boat decoration study 
Mohd Rohaizat Abdul Wahab, Zuliskandar Ramli, Nurul Norain Akhemal Ismail, Nuratikah Abu Bakar, Wan Nor Shamimi Wan Azhar

Symbolism in Traditional Malay Boat Crafting in the East Coast

was also conducted by Coatalen (1990). In the research paper, it highlights the discussions on the symbolism and relevance inherent in the traditional components of the Malay traditional boat.

This study was conducted qualitatively based on the artefacts obtained from the National Museum collection, Kelantan Museum collection, collection of Pekan Pahang Water Transportation Gallery, Terengganu Museum collection, and several boats that are still in use in Kampung Gajah, Kota Bharu, Kelantan. Interviews with several fishermen, boat makers, and local wood carvers were also held to obtain relevant information. The collection of these data will be analysed based on the forms, motives, and relevance inherent in the traditional Malay boat decoration components.

\section{MALAY TRADITIONAL BOAT CRAFTING}

This Malay traditional boat is often used by fishermen to catch fish, carry merchandise, and as a means of transportation. According to Firth (1990) there are 9 types of boats used by the coastal fishermen in Kelantan and Terengganu. Whereas, Alfred (1997) lists 12 types of boats used by the coastal fishermen in Pahang. Studies on this type of boat were also carried out by other researchers, such as Smyth (1902), Gibson-Hill (1954), and Mohd Yusof Abdullah (1999). These traditional Malay boats mostly have wood carvings and paintings modelled on linggi, bangau, okok, caping, koyang, cagak, which are displayed on the paddles and the boat body as in Figure 1 below.

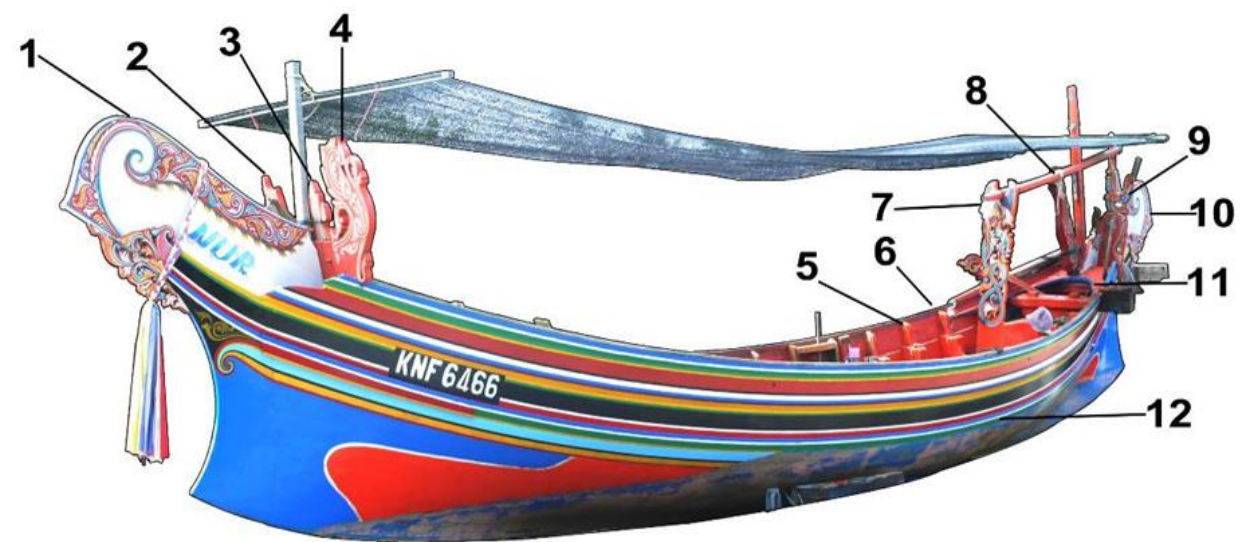

Figure 1 The structure of the decoration components on Western Boat
1. Kepala
2. Okok
3. Caping
5. Kong
9. Sangga Kemudi / Cagak
4. Bangau
6. Papan Leper
10. Ekor
7. Sangga Tengah
11. Papan Edek
8. Koyang
12. Papan Tua / Papan Timbal

The decoration component is produced by boatman and some of them are made by the owner of the boat. This component has its own function and is crafted 
PLANNING MALAYSIA

Journal of the Malaysia Institute of Planners (2018)

carefully and artfully. For example, the bangau serves as a mast and a long pole that are used by fishermen to sail and set the nets. Okok or anak bangau are used as an instrument for the anchor rope. Usually, the fishermen will remove the bangau and okok when the boat is landed. The caping, which is located at the middle between the bangau and okok, serves as a bangau-okok holder. Fishermen will put the bangau in front of the caping when they descend to the sea. The caping is permanently installed with boat keel and covered with papan edek. The decoration component is well maintained and preserved neatly and with great care as not to cross any taboo-related boundaries. The koyang is used to support the boat rowing paddle. The sangga is also used to support the long pole used by fishermen. These components are carved and painted with a variety of motifs and symbols that are closely related to the old traditional beliefs from previous generations.

\section{THE USE OF MOTIFS ON BOAT DECORATIONS}

In this study, some forms resembling pre-Islamic images are found on the boat decoration component. Images such as the makara can be seen on the head and tail of the boat, while the engraving of the motifs can be found at each end of the bangau. This makara statue can be seen at the front of the entrance of the temple, which serves to safeguard the fishermen from evil spirits. According to myths and beliefs of Hinduism, the makara is a type of sea animal used by the God Vishnu during his travel at sea (Mohd Sabrizaa, 2008).

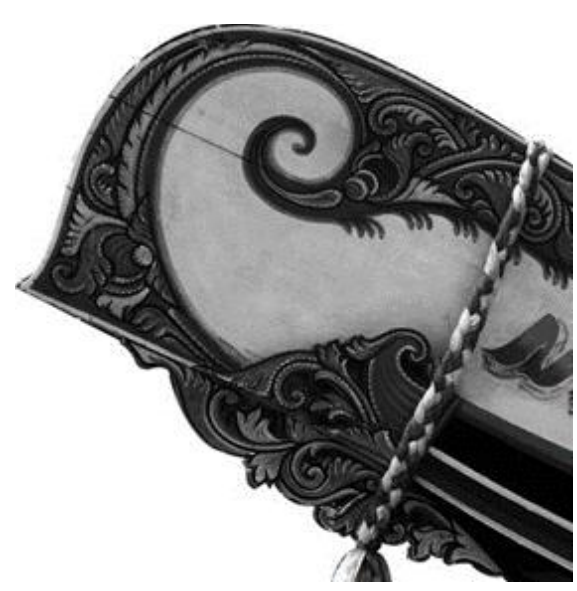

Figure 2: Kepala perahu

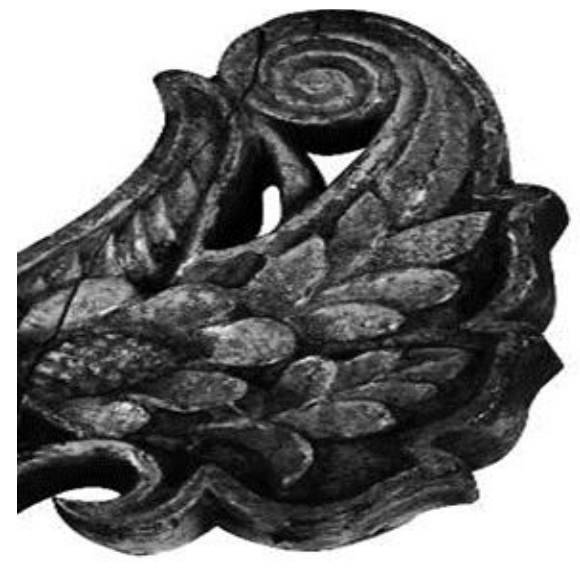

Figure 3: Bangau 
Mohd Rohaizat Abdul Wahab, Zuliskandar Ramli, Nurul Norain Akhemal Ismail, Nuratikah Abu Bakar, Wan Nor Shamimi Wan Azhar

Symbolism in Traditional Malay Boat Crafting in the East Coast

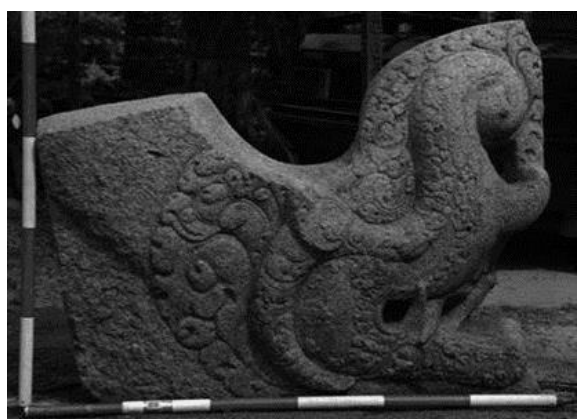

Figure 4: Makara

The dragon image is also evidently used on many components of the boat decoration on the East Coast. Images of the dragon are often found in the linggi part, with the shape of the bangau (along with the motifs on it, okok and the paintings on the body of the boat. The dragon is a creature that lives in the water, and in the Malay community, the dragon is a symbol of saviour and keeper of the earth. It also represents fertility, as the dragon keeps the balance of water and thrives in it. The dragon is also regarded as the guardian of the fishermen's safety while they are at sea. The use of this dragon image is often present in the bangau carving, where the dragon's carvings are combined with plants motifs.

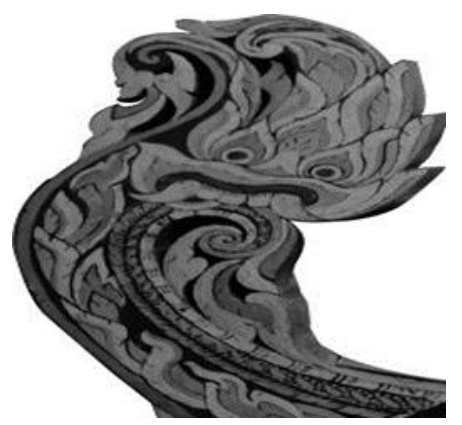

Figure 5: Dragon I

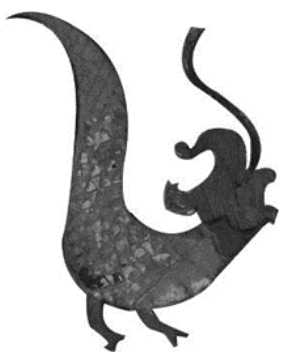

Figure 7: Dragon III

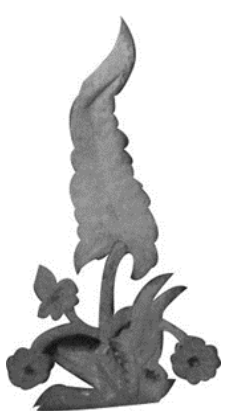

Figure 6: Dragon II

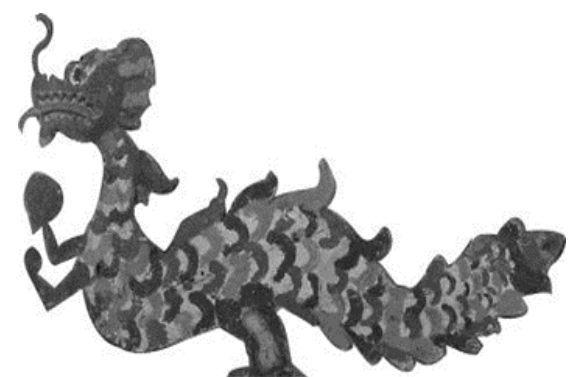

Figure 8: Dragon IV 
PLANNING MALAYSIA

Journal of the Malaysia Institute of Planners (2018)

Caping is a piece of wood that is shaped like an oval betel and carved full with creeping plants motifs. It is also described as the ficus tree (pohon beringin) or the bodhi tree, which is considered sacred to the Malay community. The caping is permanently installed on the boat and cannot be moved. Much like the ficus tree, the caping stands firm, strong and is unshakeable. The lush and tall ficus tree is a place of shelter for various types of birds and animals. In ancient Malay belief, the ficus tree is the home of guardians and supernatural creatures. During the previous generation's practice, the shaman will conduct a ceremony honouring the spirit of the boat with a spell. In the process, the areca nut, coconut blossom, and paan are placed on the caping (Mohamad, 1989). The fishermen community considers the caping part as the most important part of a boat as it serves as a guardian of the fishermen's safety.

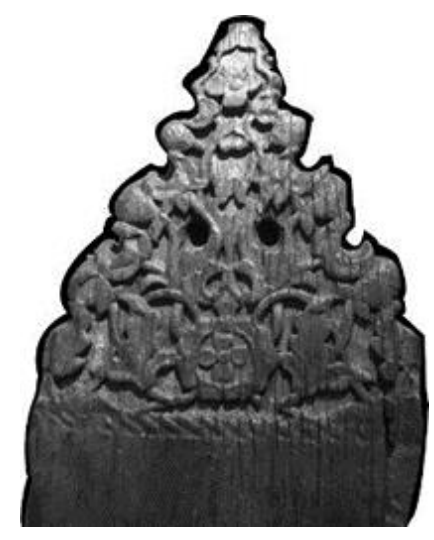

Figure 9: Caping I

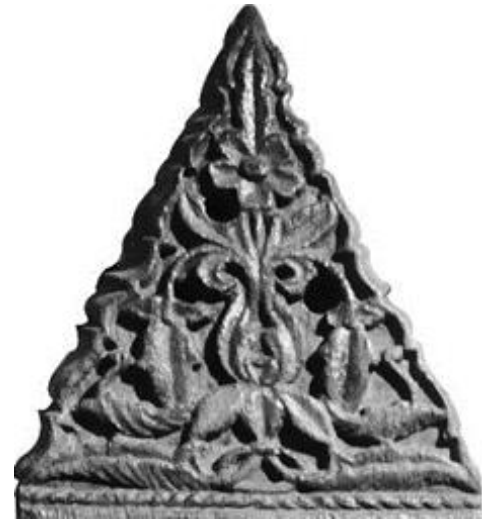

Figure 10: Caping II

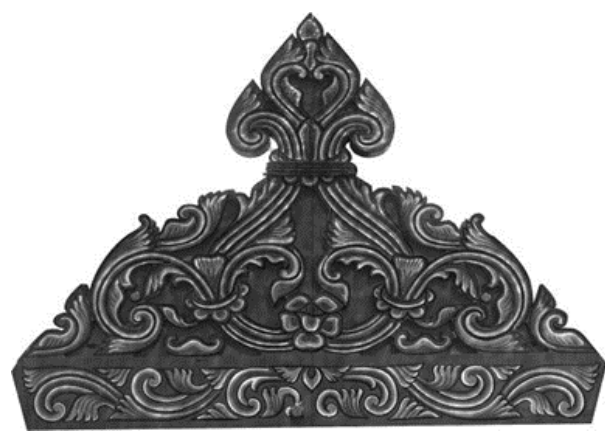

Figure 11: Caping III

Bird images are often used in Malay art, especially on the head of keris. In Hindu myths, birds are used by the God Vishnu as a mode of air transportation. Birds are also associated with animals that are loyal and strong, like the Petalawati Bird character in the Hikayat Ramayana story. According to Siti 
Mohd Rohaizat Abdul Wahab, Zuliskandar Ramli, Nurul Norain Akhemal Ismail, Nuratikah Abu Bakar, Wan Nor Shamimi

Wan Azhar

Symbolism in Traditional Malay Boat Crafting in the East Coast

Zainon (1985) in the Malay community, birds represent spirit, strength, and pride. Birds are also a form of transportation, which are also associated with the symbol of sustenance. The image of the bangau is also associated with the characteristics of a stork that is capable of observing and catching fish. Bird motifs are widely found on the linggi, bangau, okok, koyang, sangga and boat body.

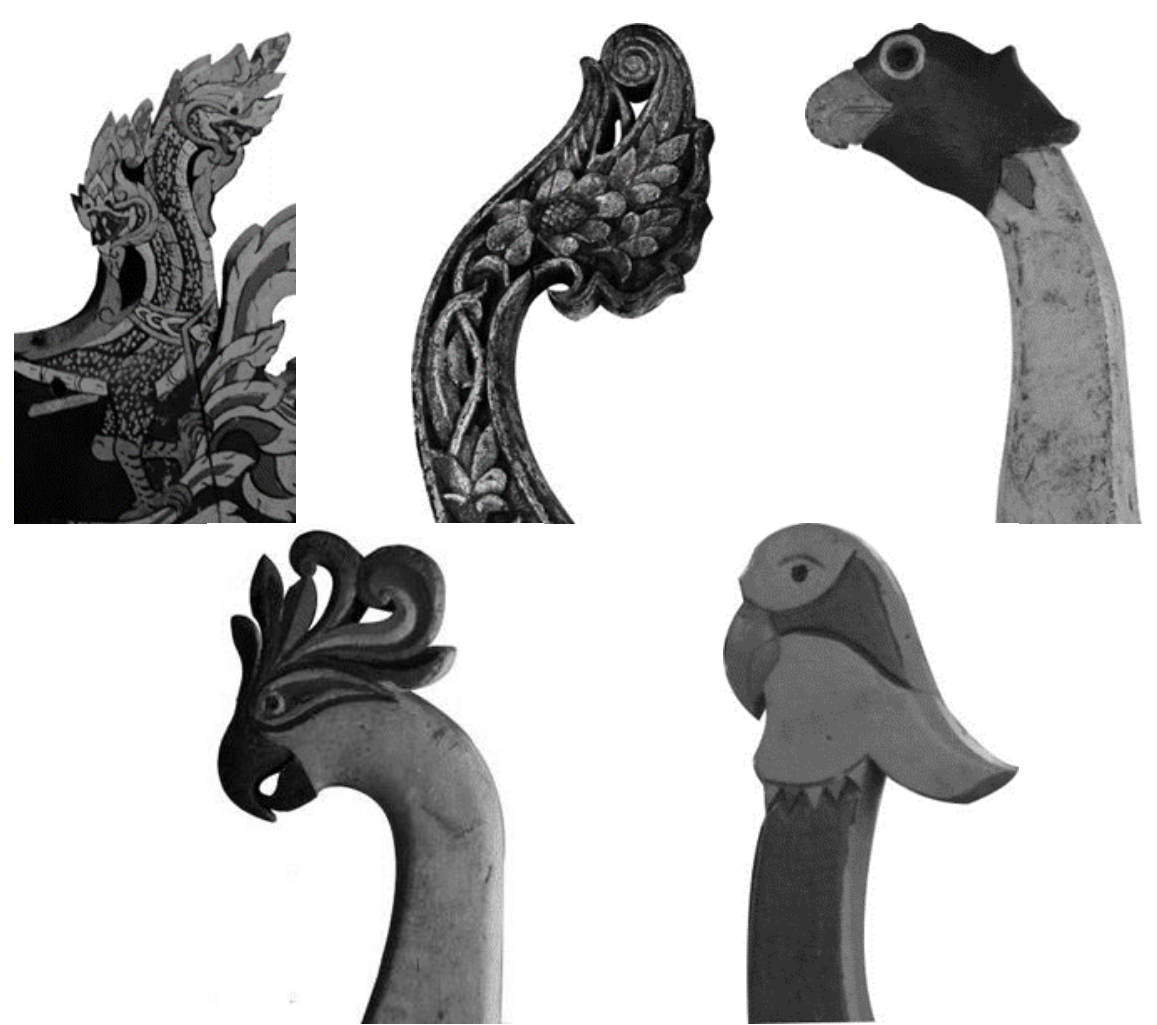

Figure 12: Some of the bird images of boat decoration

The discovery of some forms and motifs on this traditional Malay crafting art can be concise, as shown in Table 1. The creation of these forms and motifs are the continuity of the arts inherited from previous generations. The motifs of geometry, cosmos, flora, and fauna are an artistic feature in the East Coast. The selection of this motif is also based on the ethics that has long existed in the fishermen's culture. It is also associated with taboo and ritual practices that fishermen are obliged to do before and during their work. 
Table 1: Types of motifs used in decoration components

\begin{tabular}{|c|c|}
\hline Decoration Component & Shape and Motifs Used \\
\hline Linggi & $\begin{array}{l}\text { Makara, dragons, birds, geometry and plants, currents } \\
\text { themes such as scenery. }\end{array}$ \\
\hline Bangau & $\begin{array}{l}\text { Birds, Flowers, Plants, shadow puppets, dragons and } \\
\text { makara. }\end{array}$ \\
\hline Okok & Flowers, Birds, plants, shadow puppets \& dragons. \\
\hline Caping & Flowers, Birds, plants, shadow and ficus trees. \\
\hline Koyang & Birds, dragon and shadow puppet character. \\
\hline Sangga & Birds, dragon and plants. \\
\hline Dinding Perahu & $\begin{array}{l}\text { Geometry, dragons, birds, flowers, plants, fish and } \\
\text { scenery. }\end{array}$ \\
\hline
\end{tabular}

\section{CONCLUSION}

The art produced in traditional Malay carpentry is mainly founded on the three main areas of function, aesthetics, and ethics. The production and use of decoration on the boat is highly regarded by coastal communities in the East Coast. The fishermen community believes that the oceans are another being inhabited by other creatures and they deserve to be respected. Based on the findings of some of the images that are symbolic of boat decoration, motifs of animism and pre-Islamic beliefs were widely used. The production of craftsmanship on the traditional boat gives its own meaning and philosophy. It is also blended with the belief in external power that can provide security and fortune to the fishermen. Symbolism and the symbolic aspect form a working environment that is harmonious for the fishing community; however it does not adhere to the principles of Islam. When Islam was introduced to the coastal communities in the East Coast, the awareness and understanding of the society of Islamic arts are required. Belief and confidence in external power other than Allah SWT has since been abandoned. Based on religious consciousness, many changes have been made by boatmen and craftsmen on the traditional boat decoration. The use of forms and motives such as herbs, Islamic calligraphy, geometry, and abstract patterns that do not contradict with Islamic values have been used in traditional boat craft arts. The discovery of non-Islamic images is not to accuse the Malay community for its past practices and beliefs, but it can provide an example and awareness to the present community of Malay art.

\section{ACKNOWLEDGEMENT}

This research was carried out with the assistance of the research grant DCP-2017008/1 and TD-2014-005. Therefore, we would like to express our gratitude to the Ministry of Higher Education, and The National University of Malaysia (UKM) for the research grants awarded. 
Mohd Rohaizat Abdul Wahab, Zuliskandar Ramli, Nurul Norain Akhemal Ismail, Nuratikah Abu Bakar, Wan Nor Shamimi

Wan Azhar

Symbolism in Traditional Malay Boat Crafting in the East Coast

\section{REFERENCES}

Alfred, E. R. (1997). The boats of Pahang. Pekan: Lembaga Muzium Negeri Pahang.

Coatalen, P. J. (1982). The decorated boats of Kelantan. Penang: Penerbit USM.

Gibson-Hill, C. A. (1954). The boats of local origin employed in the Malayan fishing industry. Journal (Malay Branch) Royal Asiatic Society, 27(2), 145-180.

Firth, R. (1990). Nelayan Melayu: Ekonomi tani mereka. (Yaacob Harun \& Noor Hasnah Moin, Trans.). Kuala Lumpur: Dewan Bahasa dan Pustaka.

Mohamad Nor Mat (1989). Perahu tradisi Terengganu. Kuala Lumpur: University Malaya.

Mohd Sabrizaa Abd Rashid. (2008). Evolusi bentuk dan makna pada ragam hias dalam seni bina tradisional Melayu. Prosiding National Seminar Science, Technology, Social Sciences 2008 (STSS 2008). Pahang, Malaysia.

Mohd. Yusof Abdullah (1999). Pengangkutan air di Terengganu. Kertas Kerja Seminar Peranan Maritim di Terengganu. Terengganu, Malaysia.

Nik Hassan Shuhaimi Nik Abd. Rahman (2002). Sejarah Kelantan sebelum Long Yunus - Satu gambaran umum. In Nik Hassan Shuhaimi Nik Abd. Rahman (Ed.), Kelantan zaman awal: Kajian arkeologi dan sejarah (pp.1-14). Kelantan: Perbadanan Muzium Negeri Kelantan.

Nik Hassan Shuhaimi Nik Abd. Rahman (2010). Seni ukir Melayu sebagai hiasan pada perahu tradisional di Semenanjung Malaysia. In Zawiyah Baba (Ed.), Warisan seni ukiran Melayu. (pp. 117-127). Bangi: Institute of Malay World and Civilization.

Sheppard, M. (1963). 'Bangau' decorative guards for sail and spars on Malay fishing boats. Kuala Lumpur: Museums Dept., Federation of Malaya.

Siti Zainon Ismail (1985). Getaran jalur dan warna. Petaling Jaya: Penerbit Fajar Bakti Sdn. Bhd.

Smyth, H. W. (1902). Boats and boat building in the Malay Peninsula. Journal of the Society of Arts, 570-588. 